\title{
The effect of corporate social responsibility on supply chain performance
}

\author{
Thi Thu Hoai Nguyen ${ }^{a}$, Thi Thai Thuy Nguyen ${ }^{b}$ and Thi Thu Hien Phan ${ }^{\text {** }}$
}

${ }^{a}$ University of Economics and Business, Vietnam National University, Hanoi, Vietnam

${ }^{b}$ University of Economics - Technology for Industries, Vietnam

C H R O N I C L E

\begin{tabular}{l} 
Article history: \\
Received March 8, 2021 \\
Received in revised format May 5, \\
2021 \\
Accepted June 152021 \\
Available online \\
July 252021 \\
\hline Keywords: \\
Corporate social responsibility \\
Corporate reputation \\
Supply chain performance \\
Firm performance \\
Vietnam
\end{tabular}

\section{A B S T R A C T}

This study was conducted with the aim of assessing the impact of corporate social responsibility on supply chain performance through corporate reputation. The study also evaluates the effect of corporate social responsibility on corporate reputation and firm performance. The study made over 507 observations from businesses in the textile, seafood and food industries in Vietnam. The data was analyzed using SmartPLS 3.6 software, and the results showed that corporate reputation plays a full mediator role in the relationship between corporate social responsibility and supply chain performance. Corporate social responsibility has a positive impact on corporate reputation and firm performance. Finally, we offer recommendations to help businesses implement corporate social responsibility more effectively.

\section{Introduction}

In recent decades, environmental protection is a phrase that has been mentioned in many fields, both theoretical and practical. This has created a lot of pressure for businesses to change the way they operate to ensure both environmental and social values while increasing business results. According to the natural-resource-based view, Gladwin (1993) argues that, when increasing environmental pressure forces businesses to implement new strategies, they will be at a competitive advantage. It is forecasted that in the next 10 years, sustainable development will continue to be a worldwide trend, associated with the United Nations' 2030 Agenda for Sustainable Development. As a member of the United Nations Commission, Vietnam is making efforts to implement sustainable development policies while effectively building resources to implement the sustainable development goals. Vietnamese enterprises are facing challenges as well as opportunities in the process of transformation and international integration. In that context, sustainable development is a requirement of the times, therefore, enterprises play a great role in socio-economic development. Enterprises implementing social responsibility will affirm their brand in society. Davis (1973) has given a broad concept: Corporate social responsibility (CSR) is the concern and response of the business to issues that go beyond satisfying legal, economic, and technological requirements. Meanwhile, Carroll (1999) also argues that CSR has a broader scope: CSR includes the economic, legal, ethical, and philanthropic expectations of society. Matten \& Moon (2004) argue that: CSR is a cluster concept, encompassing many different concepts, such as business ethics, business as charity, corporate citizenship, sustainability, and environmental responsibility. It is a dynamic concept and is always challenged in each specific economic, political, and social context. Meanwhile, according to the World Business Council for Sustainable Development, CSR is a commitment to behave ethically and contribute to economic development, while improving the quality of life of people. workforce and their families, as well as of the local community and of society at large. Or more recently, according to the World Bank's Private Economic Development Group (WB), CSR is the enterprise's commitment to contribute

* Corresponding author Tel.: +84 0914915926

E-mail address: ptthien.kt@uneti.edu.vn (T.T.H. Phan)

(c) 2021 Growing Science Ltd. All rights reserved.

doi: $10.5267 /$ j.uscm.2021.7.008 
to sustainable economic development, through jobs that enhance the quality of life of workers and members of their families, the community and society, in ways benefits both businesses as well as the general development of society.

A review of some of the above definitions has shown that, although the expression and form of verbal expression are different, the reflected content of CSR basically has the same thing that, in addition to the development benefits, The individual development of each enterprise in accordance with the current law must be associated with the common development interests of the social community. Therefore, in our opinion, perhaps the definition of CSR by the World Bank's Private Economic Development Group on CSR is the most complete, clear, and easy to understand, because it mentioned the corporate social responsibility that must be attached to CSR associated with sustainable development - an objective, urgent, global requirement of current development. Practice shows that businesses that implement CSR well often achieve significant benefits, including reduced costs, increased revenue, increased brand value, reduced employee turnover, increased productivity and more opportunity to access new markets. CSR is a new concept that has been introduced to Vietnam for more than a decade, but in recent years, there have been many Vietnamese businesses to create a sustainable and bright brand. Therefore, implementing CSR is increasingly recognized by Vietnamese businesses and entrepreneurs as an indispensable and objective requirement in the integration process. However, both academically and practically, it should be seen that this is still a relatively new issue for many businesses and entrepreneurs in our country. In fact, there are businesses and entrepreneurs who only care about production and business so that they can make high profits, solve problems that benefit businesses and employees, and contribute to many other causes, humanitarian activities, social charity, but they still violate the Enterprise Law, the Environmental Law, or have other law violations. There are many reasons for this situation, but first, enterprises do not have a correct, objective, scientific and especially voluntary awareness in carrying out their social responsibilities to the social community. When the competition is getting fiercer, the requirements from customers are increasing and society has an increasingly strict view of businesses. Enterprises that want to develop sustainably must always comply with standards on protection of the natural environment, working environment, gender equality, occupational safety, labor rights, training, and employee development, and contribute to community development. Businesses can fulfill their social responsibility by obtaining an international certification or by applying Codes of Conduct. In fact, some Vietnamese enterprises have done so. Corporate social responsibility (CSR) is an increasingly important issue in business operations in general and in supply chains. The recent unsafe situation of food production and distribution, especially vegetables, has raised many questions about the implementation of CSR in the food supply chain, especially in developing countries such as Vietnam. So, does implementing social responsibility lead to better supply chain efficiency, better corporate reputation, and better firm performance? To answer this research question, we conduct research on three typical economic sectors of Vietnam: the textile industry, fisheries and food. Textile and garment is an economic sector with a huge export turnover and solves a large number of jobs for workers. However, Vietnamese textile and garment enterprises are mainly manufacturing outsourcing for international orders. Therefore, Vietnamese textile and garment enterprises are required to perform corporate social responsibility to ensure the conditions of the global supply chain in this industry. Like the seafood industry, seafood products are also mostly exported to developed markets such as the US, Europe and Japan. These markets have very high requirements on social responsibility standards with orders from Vietnam.

With the expectation that, the better businesses perform socially responsible activities, the higher the corporate reputation and the higher the supply chain performance as well as the firm performance. The structure of the article in addition to the introduction includes: Literature review; Research methods, research results and conclusions.

\section{Literature review}

\subsection{Corporate social responsibility}

The concept of social responsibility has emerged since the 1950s in the form of related terms such as citizenship, corporate social responsiveness, corporate social performance (Wood \& Jones, 1995). The first person to lay the foundation for the concept of social responsibility was Bowen (1953), social responsibility is the pursuit of policies, implementation of decisions and the pursuit of chains of activities with the desire to achieve goals and value of society. Following that, Carroll's studies are also considered representative. Carroll (1979) defines social responsibility as the economic, legal, ethical, and societal expectations of an enterprise in certain times. Some researchers consider social responsibility as a function of corporate behavior towards different stakeholders such as customers, suppliers, authorities, employees, investors, and the community. (Campbell, 2007). Or Devinney (2009) defines, social responsibility is the multi-dimensional activities of the company including social, political, environmental, economic, and ethical. Recent researchers have also defined social responsibility as voluntary activities performed by organizations beyond legal obligations, bringing benefits to the environment and society (Taghian et al., 2015). Malik (2015) has developed the concept of stakeholder-based, social responsibility as voluntary initiatives of enterprises towards different stakeholders such as customers, suppliers, authorities, employees, investors, and the community. This is the concept that this study inherits for further research. Carroll (1991) identified four components of social responsibility, he said that economic responsibility and legal responsibility are very important, but ethical and charitable responsibilities are also necessary to create success. of the enterprise. Today, the success of businesses is not only measured by profits, but also by the individual activities in which businesses participate. 


\subsection{Corporate Reputation}

Corporate reputation (CR) reflects stakeholders' perceptions of the organization. This perception is formed over time based on the experiences of different stakeholders and from corporate communications. Taghian et al. (2015), when it comes to corporate reputation, it is advisable to focus on management aspects because it will comprehensively consider the perspectives of stakeholders. Each stakeholder has different expectations and attitudes, so their understanding and perception of business operations will also be different. Only managers who contact all stakeholders can assess the importance of stakeholders, thereby forming the right strategy. In strategic management, reputation is viewed as a unique intangible asset that is difficult to imitate (Roberts \& Dowling, 2002; Smaiziene \& Jucevicius, 2010) that represents a set of impressions about an enterprise. from many stakeholders (Shamma \& Hassan, 2009). In marketing, reputation is seen as the bond that individuals establish with the business (Fombrun et al., 2000), a force to attract customers (Davies et al., 2003) and to encourage loyalty to their city (Seleim et al., 2007). Based on similarity of definitions across sectors, Fombrun (1996) defines corporate reputation as "a cognitive representation of a firm's past actions and a description of its overall future prospects. business for all its key parties when compared to other leading competitors". Fombrun (1996) was the first to systematically define a firm's reputation, and although his definition has been developed, the original version remains the most cited (Walker, 2010). Ferguson et al. (2000) define reputation as the understanding of the true characteristics of a business and the feelings towards the business held by stakeholders. Reputation is also defined by Mahon (2002) as an evaluation of a person or thing that is influenced by the characteristics of that person or thing, which can also be constituted by human behavior and cooperation with other parties. Reputation is also described as the cumulative collective decisions and evaluations of the business by stakeholders (Barnett et al., 2006). Rindova et al. (2005), also describe corporate reputation as the perceptions and beliefs that stakeholders have in the business. Siltaoja (2006) defines reputation as an enduring combination of external assessments of the organization and how well it is delivering on its commitments and meeting stakeholder expectations.

Walker (2010) observed that three important attributes are ascribed to the reputation of the business based on the definition of Fombrun (1996): (1) based on perception; (2) is the aggregate perception of all stakeholders; and (3) is comparison. Furthermore, Walker (2010) identifies two other attributes that are combined by later literature (4) reputation that can be either positive or negative; and (5) is stable and long-lasting. He said that a business can have many reputations depending on which stakeholders and what specific issues are considered, but each reputation represents the aggregate perception of all stakeholders on an issue. specific topic. Thus, based on Fombrun (1996) and subsequent academic discussions, Walker (2010) defines a firm's reputation: Relatively stable, problem-specific synthesis representative of perceived behaviors, past performance of an enterprise and its prospects when compared with a number of standards. While there are different ways to interpret a business reputation, reputation can be defined as follows: Stakeholders perceive and evaluate past actions of the business through direct experience. Directly and indirectly, the results create awareness for businesses. They then use these results to predict and build future responses to the business. Therefore, this study describes corporate reputation as the aggregated perception of the past actions of the enterprise and describes the future prospects of the business to stakeholders. The most important stakeholders that affect the reputation of a business are customers and employees. Therefore, in this study agreeing with Taghian et al. (2015), corporate reputation is measured by managers' perception of the opinions of all stakeholders, not considering the opinion of a particular interested party. At the same time, the study also inherits the scale from Taghian et al. (2015) to build a scale for this research concept.

\subsection{Supply chain performance}

Supply chain performance is very often considered when compared to company performance. There we have financial and non-financial performance measures, though. One model used to measure financial performance at the supply chain level is governance value analysis (GVA), proposed by Gosh and John. It considers two elements of value created: relational value (shared profit) and agent value (shared profit). Based on these two values, the authors attempt to prove the relationship between the two firms, mainly using the theory of transaction cost economics (TCE). Several other studies have extended the value chain creation measurement from the Balanced Scorecard (BSC) to the Supply Chain Operations Reference Model (SCOR) (Barber, 2008). The truth is that there is no universally accepted methodology for measuring value creation in the supply chain, all they suggest is that performance cannot be measured with just one key performance indicator from a side of the business that must use more than one performance indicator. If we consider the negative outcomes that a supply chain can produce, such as a bad reputation, bad image for customers, loss of trust from customers and other organizations - the situation becomes more and more confused. However, perhaps an overall supply chain performance score would include positive effects and negative effects. A generally accepted issue is the fact that performance must be measured at the corporate level and not for each part of the supply chain. This acceptance ensures that supply chain management can be seen as one of the possible causes of joint supply performance in the future.

\subsection{Firm performance}

The phrase Firm performance is widely used in many areas of management. Although widely used, the exact meaning is rarely expressed explicitly (Lebas \& Euske, 2006), often business results are understood as efficiency and efficiency (Neely et al., 2005), or lean production, competitiveness, cost reduction, value addition and employment, growth and survival of the business. Hasan \& Ali (2015) define business results as a reflection of perceived benefits that they expect when implementing 
environmental governance in operating business operations; Specifically, increasing the good image of the business, reducing waste, minimizing costs, increasing customer satisfaction, increasing productivity, increasing market share and profit. However, from the point of view of stakeholder theory, many studies on business results suggest that when businesses treat well and operate for the benefit of stakeholders, they will help businesses create value, performance changes (Freeman, 1984; Harrison \& Wicks, 2013). Freeman (1984) defines business outcome as the total value generated by the business through its activities, which is the sum of the utilities generated for each of the legitimate stakeholders of the business. Phillips (2003) defines legitimate business stakeholders as those involved in, constituting the organization and the business has obligations to them. They include customers, the communities in which the company operates, suppliers of capital, equipment, materials, and employees. Businesses in different sectors may have different legal stakeholders. Thus, business results are a multidimensional concept, this study will continue to study business results associated with stakeholders such as Freeman's concept of business results as the total value created generated by the business through its activities, which is the sum of the utilities generated for each of its legitimate stakeholders (Freeman, 1984). Since the early years of the 20th century, DuPont has proposed a pyramid of financial ratios with a series of indicators to measure business performance, but Johnson \& Kaplan (1987) have pointed out shortcomings in this approach. This pyramid shows failures using only financial measures in the competitive and strategic context of modern businesses. Keegan et al. (1989) proposed a matrix measurement framework that reflects the need to measure equilibrium. Measures are classified as "cost" or "no cost", "external" or "internal", with this matrix allowing the business to determine where to focus the assessment. Fitzgerald et al. (1991) proposed a framework for classifying measures into two basic categories. Factors related to results (competitiveness, financial performance) and factors determining results (quality, flexibility, resource utilization and innovation). This reflects on causality; the firm obtains future results that are related to specific past determinants. This demonstrates the need to define a process to achieve the desired results. The most popular business performance measurement framework is the balanced scorecard of Kaplan \& Norton (1992), which identifies and integrates four different views of business performance (financial, customer, operating internal, innovation and learning perspectives). The balanced scorecard gives equal weighting between financial results and continuous improvement results. The authors suggest that considering the balance of the scorecard can help businesses devise their strategies. The Kaplan \& Norton (1992) model mentioned many stakeholders as directly measuring customer perception and employee problems to build their internal effectiveness, but they left some parties - key stakeholders out, such as suppliers and the community.

\section{Research Methods}

\subsection{Research sample}

To examine the impact of social responsibility on supply chain performance and Firm performance, we conducted a survey on Vietnamese enterprises across 3 main industries: Textile, Fisheries and Food. We choose these 3 industries because in Vietnam, the textile industry requires CSR is very important. CSR affects the survival and development of Vietnamese textile and garment enterprises because Vietnamese textile and garment enterprises mainly operate in the form of processing and manufacturing to order and must ensure the following conditions: on CSR of major foreign partners. Second, we choose the seafood industry because Vietnamese seafood enterprises are like Vietnamese textile and garment enterprises. The market for seafood products is mainly exported to major markets such as the US, Europe, Japan, etc. Therefore, the requirements for CSR are very strict. CSR activities and standards become mandatory for each export order of Vietnamese seafood enterprises. Finally, we want to study an industry that is completely opposite to the characteristics of the textile and seafood industries, which is the food industry. Vietnam's food products are mainly consumed domestically with the consumer market still quite "easy". In the Vietnamese market, there are many cases of food poisoning, food that does not meet the standards of food hygiene and safety. So, do caterers practice social responsibility? What is the business performance of the catering units that has prompted us to study a contrasting case with the above two industries? From the research objective, we sent all 1000 survey questionnaires via email and directly to leaders and heads of departments of textile, food, and seafood enterprises. As a result, 756 questionnaires were collected. After that, we entered data and screened the remaining 507 valid questionnaires for analysis. Of which, 181 are textile enterprises, 172 seafood enterprises, and 154 food enterprises.

\subsection{Research model and research hypothesis}

\section{Research models}

The theory of social responsibility and the theory of green marketing is the basis to support the point that, when businesses want to increase business results, it is necessary to have the right strategies and show their responsibility throughout the process of business execution. In recent years, many authors have conducted exploratory as well as empirical research to understand the relationship between green marketing for branding and business performance (Ginsberg \& Bloom, 2004), the relationship between social responsibility and business performance (Malik (2015); Taghian et al., 2015); Phan et al. 2020; Le et al. 2019), the relationship between social responsibility and green supply chain, supply chain performance (Lindgreen et al., 2009; Phan et al. 2020; Le et al. 2019; Nguyen et al., 2020). Some authors have also found that corporate reputation is a concept affected by green marketing strategy (Vaccaro, 2009), by responsibility (Taghian et al., 2015), while corporate reputation increases business performance as does financial performance and supply chain performance (Taghian et al., 2015; Phan et al. 2020; Le et al. 2019; Nguyen et al., 2020). The relationship between these concepts is shown in detail as follows: 


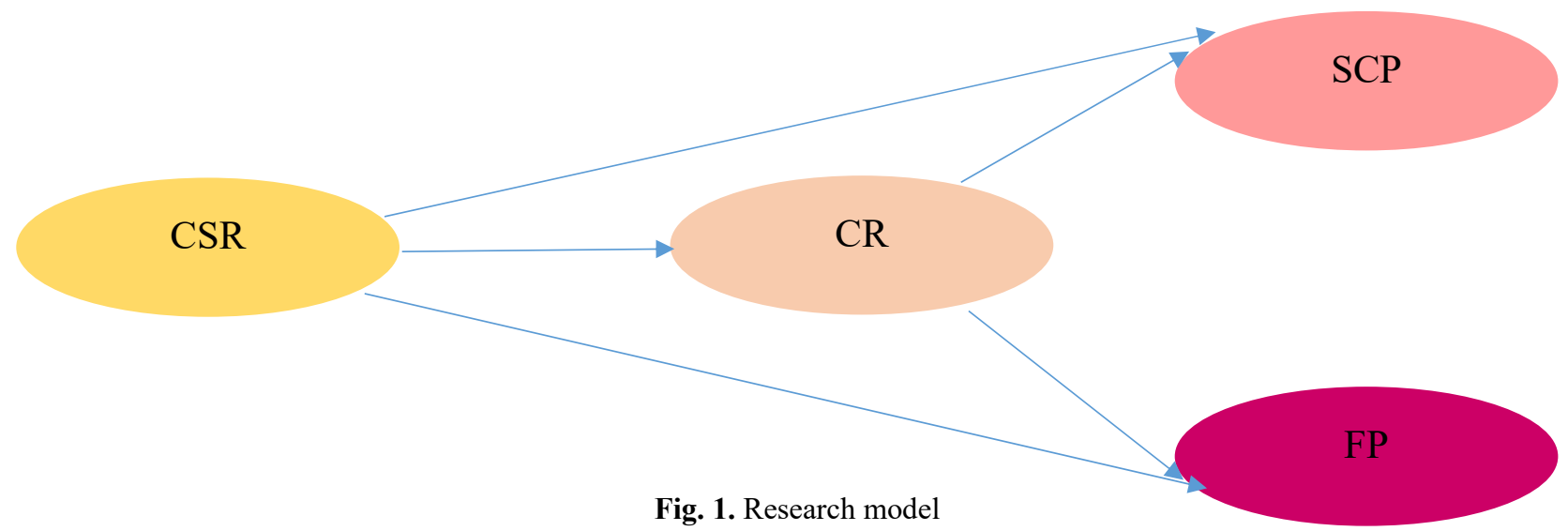

Inside:

Corporate Social Responsibility (CSR): Measured by 10 inherited items developed from the study of Maignan et al. (2005); Karna et al. (2003); Taghian et al. (2015), Le et al. (2019); Phan et al. 2020; Nguyen et al., 2020; Phan et al. (2019). All scales are measured using a 5-point Likert scale with 1 being strongly agree and 5 strongly disagree.

Corporate Reputation (CR): Reputation represents the image of a business that is known to everyone as a reputable business, good product quality, etc. Reputation is measured by 5 items developed from the research of Taghian et al. (2015); Phan et al. (2020). All scales are measured using a 5-point Likert scale from 1 to 5 with 1 being strongly agree and 5 strongly disagree.

Supply Chain Performance (SCP): Represents an efficient supply chain from the supply of raw materials to the production and consumption of products. Supply chain performance is measured by 5items developed from the study by Li et al. (2002); Phan et al. (2020); Le et al. (2019); Nguyen et al. (2020); Tran et al. (2020). Items are measured using a 5-point Likert scale with 1 being strongly agree to 5 being strongly disagree.

Firm Performance (FP): The financial and non-financial performance of a business. For the financial aspect, it is to achieve the expected profit, good revenue growth, etc. for the non-financial aspect, it is to ensure the benefits for employees, satisfied and loyal customers to the business, etc. Firm performance is measured by 5 items developed from the research of Li et al. (2002); Items are measured using a 5-point Likert scale with 1 being strongly agree to 5 being strongly disagree.

\section{Research hypotheses}

Corporate reputation will help shape consumer attitudes and perceptions about that business, which in turn will boost consumer buying motivation and help position the brand. Many studies (Lai et al., 2010; Lii \& Lee, 2012) have shown that consumer buying behavior is greatly influenced by corporate reputation. Therefore, businesses need to build a reputation for themselves through many activities, in which corporate activities related to social responsibility can greatly affect business reputation (Lii \& Lee, 2012; Phan et al., 2020; Le et al., 2019).

Carroll and Shabana (2010) find that, to increase consumer awareness, improving corporate image, reputation and social responsibility is a proposed strategic tool to do this. Lai et al. (2010) argue that social responsibility activities have an impact on the corporate reputation. Lii and Lee (2012) find that the social activities of enterprises play an important role in shaping corporate reputation in the perception of stakeholders. Research by Taghian et al. (2015) has also found that socially responsible activities will increase corporate reputation, help businesses better position themselves, and enhance competitive advantages. From the above arguments, the following hypothesis is proposed:

\section{$\mathbf{H}_{1}$ : Corporate social responsibility has a positive impact on corporate reputation.}

The relationship between social responsibility and business performance is also found in many previous studies. Aras et al. (2010) has found many studies that say there is a negative relationship between social responsibility and business performance or no relationship with each other (Aupperle et al., 1985). However, there are also many authors who have studied to find a positive relationship between social responsibility and business performance such as Malik (2015); Taghian et al. (2015). Therefore, this study proposes the hypothesis:

$\mathbf{H}_{2 \mathbf{a}}$ : Corporate Social Responsibility has a positive impact on Firm Performance.

$\mathbf{H}_{2 \mathbf{a}}$ : Corporate Social Responsibility has a positive impact on Supply Chain Performance.

$\mathbf{H}_{2 \mathrm{c}}$ : Reputation mediates the relationship between corporate social responsibility and supply chain performance.

When businesses build a reputation, they also position their image in the perception of consumers and stakeholders (Neville $\&$ Menguc, 2006). This is the motivation that customers will choose them when deciding to consume. Neville and Menguc 
(2006) have shown that there is a link between corporate reputation and firm performance. Social responsibility activities will affect the business's reputation and lead to an increase in business results (Lai et al., 2010). Taghian et al. (2015) found that corporate reputation had an impact on market share but had no direct impact on profitability. From here, the author proposes the hypothesis:

\section{$\mathbf{H}_{3 \mathbf{a}}$ : Corporate reputation has a positive impact on Firm performance.}

H3b: Corporate reputation has a positive impact on supply chain performance.

\subsection{Analytical techniques}

We conduct data analysis in two phases. In the first stage, we test the reliability of the scale using SPSS 23 software. After that, we test the research hypotheses using Smart PLS 3.6 software in detail as follows:

- Quantitative analysis technique using SEM model is one of the widely applied methods in many fields because of its flexibility in modeling relationships between concepts. In SEM model, there are usually 2 types: (1) Based on covariance (CBSEM - Covariance-based SEM) through AMOS, LISREL software; (2) Based on the variance through the method of least squares (VBSEM - Variance based SEM, also known as PLS-SEM) used by SmartPLS software. The SEM method is widely used in many fields, including economics (Henseler et al., 2009; Hair et al., 2011).

The topic uses SmartPLS 3.6 software with PLS-SEM technique to test the theoretical model. According to Hair et al. (2014), the number of studies using PLS-SEM published in recent years has increased rapidly. In the fields of organizational behavior, information system management, strategic management and in marketing research because PLS-SEM has many advantages over CB-SEM in the following situations: (1) Acceptance small sample size, data not normally distributed; (2) Can be used for complex research models with many intermediate, regulatory, latent and observed variables. Especially the structural model; (3) Capable of analyzing the structure of the result model (Reflective) and the cause model (Formative); (4) Suitable for predictive-oriented studies (Henseler et al., 2015).

In addition, if non-normally distributed data are a big problem for CB-SEM (ie: CB-SEM requires normally distributed data, this is said to be very difficult since studies are often survey using the non-probability convenience method). However, PLSSEM is "very powerful" when using non-normally distributed data (Hair et al., 2014).

According to Hair et al. (2014), when using PLS-SEM technique, it is necessary to verify through 2 steps: (1) Check the measurement model; and (2) Verify the structural model. As follows:

(1) Evaluation of the measurement model:

- Reliability of indicator variables (or called observed variables)

In the outcome model (Reflective model), the indicator variables are explained by the latent variable, the loading factor of the indicator variables $>=0.7$ (or 0.40 is acceptable in exploratory studies (Hair et al., 2011).

- Intrinsically consistent reliability

Intrinsically consistent reliability is measured through Cronbach's alpha value (Henseler et al., 2015) with an acceptable value of 0.7 in the initial research periods and each latent variable must have at least 2 indicator variables.

- Convergence value

Convergence value evaluates the relationship between indicators measuring the same latent variable. The convergence value of the scale is evaluated through:

For exploratory studies, the composite confidence coefficient (CR) is in the range of $0.6-0.7$, but ideally should be $\geq 0.7$;

The external load coefficient of the observed variables must be $\geq 0.708$;

Average variance extracted AVE (Average variance extracted, reflecting the overall variability of observed variables calculated by latent variables) must be $\geq 0.5$ (Henseler et al., 2015); and Coefficient rho_A $>0.7$.

discriminant validity

Discriminant validity measures discriminant validity to help ensure that there is no correlation between the factors used to measure the factors. Discriminant value is an important criterion in measurement model analysis. It measures the distinction between concepts in the research model (Henseler et al., 2015). There are two levels when considering discriminant validity, which are:

The degree of distinction between components in the same concept (within construct, if it is a concept of level 2 or higher);

The degree of cross construct between different concepts, or it refers to the critical measurement model (saturated model, 
the concepts in the research model are free to relate to each other).

The discriminant value is said to be eligible while the value of the criterion HTMT (heterotrait - monotrait) $<0.85$ (Henseler et al., 2015) or using the square root AVE of each measure is larger than the system. Latent variable correlations between that factor and other factors.

In addition, in evaluating the measurement model, it is necessary to evaluate the multicollinearity of the indicator variables (VIF value $<5$, no multicollinearity). Henseler et al. (2015) said that, to be able to conclude that the model fits the market data (goodness of model fit), the following coefficients need to be satisfied:

Coefficient SRMR (standardized root mean square residual) $<0.082$ (if the exploratory research type can accept $<0.12$ );

Coefficient d_ULS $<95 \%$;

Coefficient d_G1<95\%;

Coefficient d_G2 $<95 \%$

(1) Evaluation of the structural model

The second step in PLS-SEM analysis is to evaluate the structural model through Boostrapping method with sample size of 5000 (return-sampling). According to Hair et al. (2011) proposed indicators in the evaluation of structural models include:

1) The coefficient of determining the variation of the model $\left(R^{2}\right)$,

2) Degree (intensity) of influence $\left(\mathrm{f}^{2}\right)$

3) The influence factor (B) includes t values and confidence intervals,

- The coefficient of determination of the model's variation (Coefficient of determination, $\mathrm{R}^{2}$ )

The $\mathrm{R}$ tri value is defined as the percentage of variation in endogenous variables that is explained by exogenous variables (Chin, 2010,). The $\mathrm{R}^{2}$ Giá value ranges from 0 to 1 . The closer $\mathrm{R}^{2}$ is to 1 , the better the model fits the dataset. The closer $\mathrm{R}^{2}$ is to 0 , the less suitable the model is. Therefore, $\mathrm{R}^{2}$ results are important indicators of the relationship between latent variables in the model and are the main criteria for evaluating structural models (Hair et al., 2011).

Henseler et al. (2015) show that the acceptable level of $\mathrm{f}^{2}$ depends on the research context. However, the rating is still given for reference respectively: strong (0.67), medium (0.33) and weak (0.19).

- Degree of influence (Effect size, $\left.\mathrm{f}^{2}\right)$

Also according to Henseler et al. (2015) to consider the impact of exogenous variables on endogenous variables, it is necessary to evaluate the influence coefficient $\mathrm{f}^{2}$. When $\mathrm{f}^{2}$ is at 0.02 levels; 0.15 and 0.35 , it can be concluded that the impact level is weak, fair and strong, respectively.

- Path coefficient estimates

The coefficient of influence (B) provides information about the strength of the relationship between exogenous and endogenous variables. The value of $\beta$ also indicates the directional relationship (positive or negative) of the concept in the research model (Henseler et al., 2015), corresponding to the tested hypothesis. To determine the significance of the relationship, the Bootstrapping approach is proposed (Chin, 2010). The Bootstrapping method uses resampled sampling $(n=5000)$ to estimate the accuracy of the PLS estimates by replacing sampling from the original data set (Chin, 2010). The results of the $\mathrm{t}$-statistic can be used to determine the significance level ( $\mathrm{p}$-value). Accordingly, the statistical value $\mathrm{t}=1.6497$ corresponds to the $90 \%$ confidence level; $t=1.9676$ corresponds to $95 \%$ confidence and $t=2.5916$ corresponds to $99 \%$ confidence.

\section{Research results}

In an increasingly developed world of information technology, the trend of globalization and internationalization has become an objective necessity. Trade between countries is growing strongly, the competition between businesses is also increasingly fierce. In the past, companies used the method of diversifying product designs and improving the quality of goods as effective competitive measures to gain an advantage in the market. Currently, companies paying attention to strengthening their image, enhancing their reputation, developing their brand through building corporate culture and business ethics is a solution that is being applied and initially brought positive effect. Enterprises who want to affirm their brand in the market, what they are aiming for now is the good implementation of corporate social responsibility. Corporate social responsibility is a growing trend in the world, becoming a "soft" requirement for businesses in the integration process, but in Vietnam this issue is still quite new and not yet recognized. businesses pay due attention. A series of serious cases of environmental violations, violations of workers' rights, infringing on the interests of consumers ... have been causing the community to be frustrated and 
lose confidence in businesses. Since then, Vietnamese businesses are more aware of the benefits of implementing social responsibility for businesses, which is necessary in the current context of our country. We have surveyed Vietnamese enterprises in three main industries: Textile, garment, seafood and food with the corresponding number of enterprises: 181; $172 ; 154$. The results of testing the reliability of the scale show that all scales satisfy the condition with Cronbach Alpha coefficient $>0.7$ and total variable correlation $>0.4$. However, there are observed variables CSR3,4,7; FP5 and CR4 have total variable correlation coefficient $<0.3$, so we excluded them from the research model. After removing the above observed variables, the EFA test results are as follows:

Table 1

The summary of KMO and Bartlett's test results Kaiser-Meyer-Olkin Measure of Sampling Adequacy. .897

Approx. Chi-Square

Bartlett's Test of Sphericity df 406 Sig. .000

$\mathrm{KMO}$ results show that $\mathrm{KMO}$ coefficient $=0.897>0.5$ with Sig coefficient $=0.000$, thus satisfying the conditions suggested by Hair et al. (2019).

Next, we tested the overall reliability of the scales on Smart PLS 3.6 software with the following results:

Table 2

Construct Reliability and Validity

\begin{tabular}{lcccc}
\hline & Cronbach's Alpha & rho_A & Composite Reliability & Average Variance Extracted (AVE) \\
\hline Corporate reputation & 0.866 & 0.872 & 0.868 & 0.623 \\
Corporate social responsibility & 0.941 & 0.943 & 0.940 & 0.692 \\
Firm performance & 0.893 & 0.895 & 0.893 & 0.676 \\
Supply chain performance & 0.915 & 0.916 & 0.914 & 0.681 \\
\hline
\end{tabular}

From the test results in Table 2, all values are satisfied. All Cronbach Alpha coefficients are larger than 0.8; Composite reliability coefficient $>0.8$ is suitable for confirmation research (Henseler et al. 2015) and AVE coefficient is both greater than 0.5 , which proves that the scales in latent variables satisfy the combined reliability and convergence of the latent variable. Next, we test the discriminant validity of the latent variables.

Table 3

Discriminant Validity (Fornell-Larcker Criterion)

\begin{tabular}{|c|c|c|c|c|}
\hline & Corporate reputation & Corporate social responsibility & Firm performance & Supply chain performance \\
\hline Corporate reputation & 0.789 & & & \\
\hline Corporate social responsibility & 0.382 & 0.832 & & \\
\hline Firm performance & 0.422 & 0.303 & 0.822 & \\
\hline Supply chain performance & 0.526 & 0.232 & 0.412 & 0.825 \\
\hline
\end{tabular}

The results show that the values on the diagonal are larger than the values outside the diagonal. The smallest value on the diagonal of 0.789 is still larger than the maximum value off the diagonal of 0.526 . This proves that the research variables in the research model ensure the discriminant validity, which is sufficient to perform the next tests.

Table 4

R Square

\begin{tabular}{lll}
\hline & R Square & R Square Adjusted \\
\hline Corporate reputation & 0.346 & 0.343 \\
Firm performance & 0.401 & 0.495 \\
Supply chain performance & 0.477 & 0.472 \\
\hline
\end{tabular}

From the results in Table 4, it shows that the $\mathrm{R}$ - square coefficient of the corporate reputation variable is greater than 0.33 and less than 0.67 , so the model explains the variation of corporate reputation at a moderate level (Henseler et al., 2015). Similarly, the R - square coefficient of Firm performance and Supply chain performance is also in the range of values greater than 0.33 and less than 0.67 , which means that the model can moderately explain the variation of these two pre-hidden variables (Henseler et al., 2015). 
Table 5

f Square

\begin{tabular}{|c|c|c|c|c|}
\hline & Corporate reputation & Corporate social responsibility & Firm performance & Supply chain performance \\
\hline Corporate reputation & & & 0.219 & 0.309 \\
\hline Corporate social responsibility & 0.171 & & 0.321 & 0.256 \\
\hline Firm performance & & & & \\
\hline
\end{tabular}

According to Hair et al. (2017) and Henseler et al. (2015) coefficient $f$ - square has important significance in assessing the importance of control variables. In this study, we do not use control variables, so this coefficient is significant to evaluate the association between endogenous and exogenous variables. The results in Table 5 show that the coefficients of $f$ - square are both greater than 0.15 and less than 0.35 , so the impact level of endogenous and exogenous variables is moderate (Henseler et al., 2015).

Table 6

The results of Fit Summary

\begin{tabular}{lll}
\hline & Saturated Model & Estimated Model \\
\hline SRMR & 0.048 & 0.062 \\
d_ULS & 0.482 & 0.797 \\
d_G & 0.415 & 0.424 \\
Chi-Square & 545.134 & 556.725 \\
NFI & 0.859 & 0.856 \\
\hline
\end{tabular}

The results of testing the suitability of the research model and research data are completely statistically significant. The indexes in Table 6 all satisfy the condition. This means that the research model has been consistent with the research data.

Next, we test the research hypotheses.

Bootstrapping test results from the structural model using Smart PLS 3.6 software are as follows:

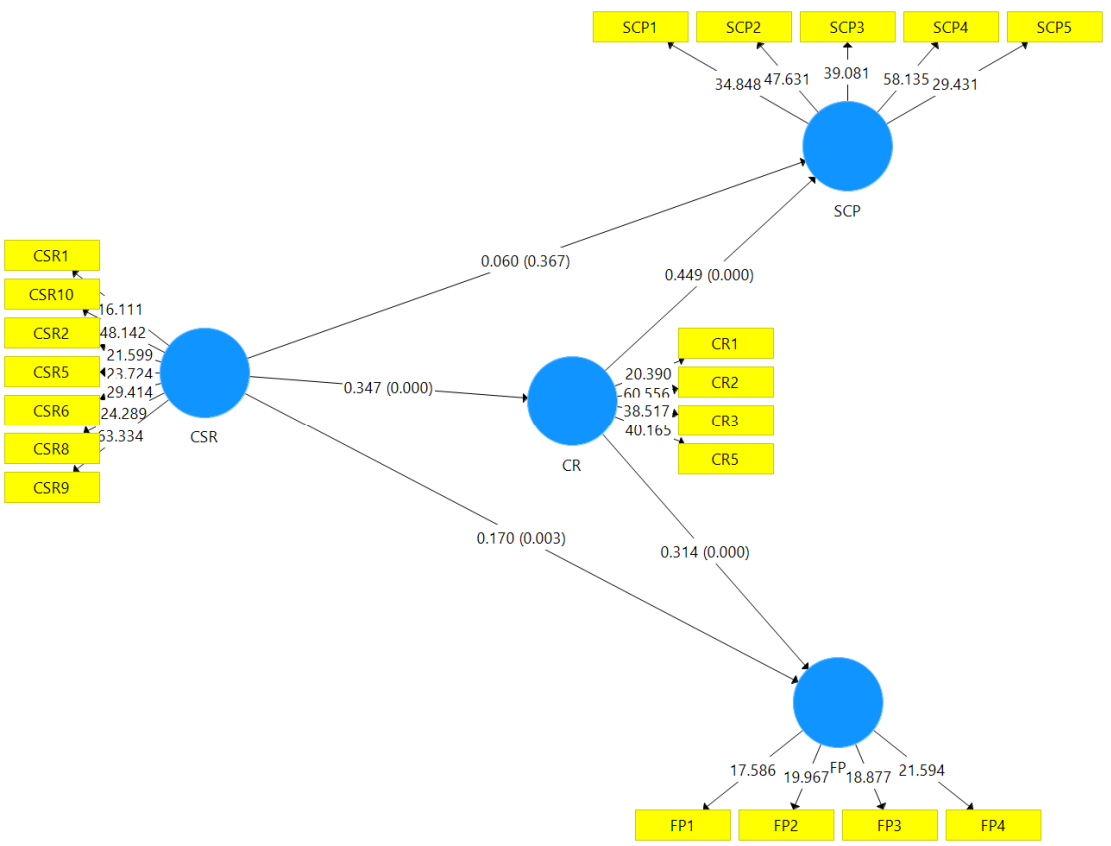

Fig. 2. Bootstrapping results

From the results in Fig. 2, it shows that corporate social responsibility has a moderate positive impact on the performance of Vietnamese enterprises with an impact coefficient of 0.170 at the $1 \%$ significance level $\left(P_{-}\right.$value $\left.=0.003\right)$. This means that when a business implements social responsibility towards its stakeholders, it will improve its business performance, but at a moderate level (Henseler et al., 2015).

Different from the relationship between corporate social responsibility and business performance. The impact of corporate social responsibility on corporate social responsibility is very strong at the 0.347 level of significance at the $1 \%$ significance 
level $\left(\mathrm{P}_{-}\right.$value $\left.=0.000\right)$. This means that in all 3 industries surveyed in the study, including: Textile, garment, seafood and food, the activities and actions of enterprises implementing social responsibility have a great impact on the image. image, brand of the business in the perception of the stakeholders in society. Therefore, enterprises should strengthen the implementation of corporate social responsibility.

Next, corporate reputation also has a very strong positive effect on supply chain performance with an impact factor of 0.449 at $1 \%$ significance level $\left(\mathrm{P}_{-}\right.$value $\left.=0.000\right)$. This means that in the supply chain of businesses, specifically textile, seafood and food businesses, corporate reputation plays a very important role. Reputation helps businesses operate in value chains and supply chains more efficiently. When a business has a good corporate reputation, the raw material supplier will actively provide good materials to ensure quality standards, time, etc. At the same time, businesses with good corporate reputation will have a good reputation with customers. Customers will also be more loyal, and customers will be more loyal, ensuring payment conditions for businesses on time, etc. Therefore, businesses need to actively build brands from corporate social responsibility activities. Karma.

Corporate reputation has a very strong positive impact on supply chain performance, so does corporate reputation have a strong positive impact on firm performance? From the Bootstrapping results in Figure 2, it shows that corporate reputation also has a very strong positive effect on firm performance with an impact factor of 0.314 at $1 \%$ significance level $(\mathrm{P}$-value $=$ 0.000). The better the business reputation, the higher the performance. Therefore, businesses need to build a reputation based on socially responsible activities.

In this study, we tested the mediating role of corporate reputation variable in the relationship between corporate social responsibility and supply chain performance. According to Hair et al. (2014) to test the intermediary role, first the independent variable and the dependent variable must have a statistically significant direct relationship, then test the level of the intermediary role according to the following steps: From survey data, the results of testing the direct relationship between corporate social responsibility and supply chain performance are as follows:

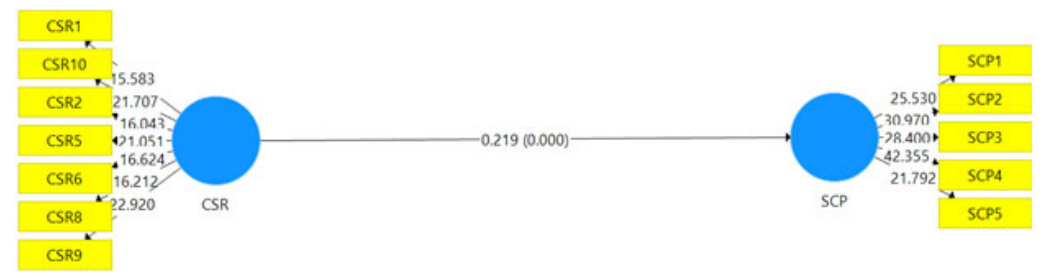

Fig. 3. Direct Relationship Results

From Fig. 3, Corporate Social Responsibility has a direct positive impact on supply chain performance with an impact factor of 0.219 at $1 \%$ significance level $\left(\mathrm{P}_{-}\right.$value $\left.=0.0000\right)$. This means that the better a business implements its corporate social responsibility, the better its supply chain performance will increase. It is easy to understand that when an enterprise implements corporate social responsibility, it means that the enterprise ensures the interests of stakeholders when participating in the value chain and supply chain. Therefore, socially responsible activities will make the supply chain smoother and more efficient. Corporate social responsibility also has a very strong positive direct impact on corporate reputation and Corporate reputation also has a very strong positive direct impact on supply chain performance such that the conditions for testing intermediaries are consistent. From the test results in the overall SEM model in Fig. 2, in this overall model corporate social responsibility no longer has a statistically significant impact on Supply chain performance. This means that corporate reputation acts as a full mediator in the relationship between corporate social responsibility and supply chain performance. The summary of the research hypotheses is as follows:

Table 7

Path Coefficients and the results of Mean, STDEV, T-Values, P-Values

\begin{tabular}{llllll}
\hline & Original Sample $(\mathrm{O})$ & Sample Mean $(\mathrm{M})$ & Standard Deviation $(\mathrm{STDEV})$ & T Statistics $(|\mathrm{O} / \mathrm{STDEV}|)$ & P Values \\
\hline $\mathrm{CR} \rightarrow \mathrm{FP}$ & 0.314 & 0.319 & 0.065 & 4.821 & 7.672 \\
$\mathrm{CR} \rightarrow \mathrm{SCP}$ & 0.449 & 0.453 & 0.059 & 0.000 \\
$\mathrm{CSR} \rightarrow \mathrm{CR}$ & 0.347 & 0.350 & 0.059 & 5.864 & 0.000 \\
$\mathrm{CSR} \rightarrow$ FP & 0.170 & 0.173 & 0.057 & 2.989 & 0.000 \\
$\mathrm{CSR} \rightarrow \mathrm{SCP}$ & 0.060 & 0.065 & 0.067 & 0.902 & 0.003 \\
\hline
\end{tabular}

From the above table to conclude, all research hypotheses are supported. The hypotheses for testing the intermediary role of corporate reputation are as follows:

Table 8

The results of specific indirect effects

\begin{tabular}{|c|c|c|c|c|c|}
\hline & Original Sample $(\mathrm{O})$ & Sample Mean (M) & Standard Deviation (STDEV) & T Statistics $(|\mathrm{O} / \mathrm{STDEV}|)$ & P Values \\
\hline $\mathrm{CSR} \rightarrow \mathrm{CR} \rightarrow \mathrm{FP}$ & 0.109 & 0.112 & 0.031 & 3.522 & 0.000 \\
\hline $\mathrm{CSR} \rightarrow \mathrm{CR} \rightarrow \mathrm{SCP}$ & 0.156 & 0.159 & 0.036 & 4.384 & 0.000 \\
\hline
\end{tabular}


From the Bootstrapping results from the model, it shows that corporate reputation has a statistically significant role in the relationship between corporate social responsibility and Supply chain performance and Firm performance. However, in the relationship between corporate social responsibility and Supply chain performance, corporate reputation plays a full mediating role. In the relationship between corporate social responsibility and Firm performance, corporate reputation plays a partial mediating role.

\section{Conclusion}

Based on assessing the actual situation of implementing corporate social responsibility in the past time, in order to raise the awareness of implementing corporate social responsibility in Vietnam in the context of integration, the article suggests some groups of solutions as follows:

On the business side

First, establish a team dedicated to social responsibility. A common practice in Vietnamese companies is that corporate social responsibility activities are often not carried out consistently and regularly. The basic reason is that in the enterprise there is no unit dedicated to corporate social responsibility. Therefore, to improve corporate social responsibility, it is necessary to establish a team dedicated to corporate social responsibility.

Accordingly, this task force should have a size and composition appropriate to the organizational structure of the business, including departments related to the selected corporate social responsibility focus issue. On the other hand, in the dedicated team, members also need to have a common understanding of corporate social responsibility and can hire more external experts to participate as part-time members to advise the dedicated team and the company. corporate social responsibility issues that are considered hotspots that need to be addressed immediately.

The establishment of a dedicated team can incur costs for the business, but this is necessary for businesses at the beginning of the implementation of corporate social responsibility, when the principles and standards of corporate social responsibility. not fully understood by employees, when corporate social responsibility activities have not been systematically implemented. Later, when the company's activities are in order, when employees have good awareness and actively implement corporate social responsibility activities, members of the dedicated team can return to work. in its divisions.

Second, strategic planning of corporate social responsibility. In production and business activities, enterprises should make a strategic plan on corporate social responsibility, because only when having a strategy can the enterprise clearly define the goals as well as the path to implement social responsibility in a proactive manner. dynamic and lasting. In strategic planning, corporate governance, with the help of a social responsibility task force, can take the following steps: Define a corporate social responsibility vision; Analyze the current status of corporate social responsibility and its impact on environmental factors to determine the priority order of issues related to corporate social responsibility, the conditions of resources devoted to the implementation of corporate social responsibility; Propose some overall solutions to implement corporate social responsibility.

On the side of state management agencies

Strengthen communication to businesses about the obligations and benefits of implementing corporate social responsibility. Propaganda can be carried out through many forms, such as through the mass media, mandatory training courses for business leaders, conferences, scientific seminars. This propaganda should be extended to the relevant state management agencies, managers, macro policy makers... At the same time, the content of the implementation of corporate social responsibility, updated information on codes of conduct, and related social responsibility standards must be fully and clearly disseminated to businesses.

Clearly delineating responsibilities of state management agencies and related subjects in policy making, information, propaganda, inspection and handling of violations of enterprises on issues related to corporate social responsibility in general, responsibility towards the market, consumers and environmental protection in particular. The coordination between state management agencies and other relevant subjects also plays a very important role, because corporate social responsibility is only valued and becomes urgent when there is a synchronous monitoring mechanism, there is a combination of government and civil forces in society, especially associations, NGOs and the media and press.

In addition, it is necessary to issue policies to encourage and support businesses to implement social responsibility. It is necessary to have strong enough measures to handle violations of enterprises in the implementation of social responsibilities, especially for enterprises producing agricultural products and food that do not meet quality standards, causing negative impacts on the environment. affect the health and life of consumers and pollute the environment; At the same time, it is necessary to strengthen forms of encouragement, encouragement, and reward for businesses that are self-disciplined and perform well on social responsibility, such as social responsibility awards, "green" brands, and certifications. for businesses to ensure the requirements related to social responsibility standards in the applicable codes of conduct.. 


\section{Acknowledgement}

This research is funded by Vietnam National Foundation for Science and Technology Development (NAFOSTED) under grant number 502.02-2020.26.

\section{References}

Barnett, M., Jermier, J. \& Lafferty, B. (2006). Corporate Reputation: The Definitional Landscape. Corporate Reputation Review, 9, 26-38 (2006). https://doi.org/10.1057/palgrave.crr.1550012

Seleim, A., Ashour, A., \& Bontis, N. (2007). Human capital and organizational performance: A study of Egyptian software companies. Management Decision. 45(4), pp. 789-801. Doi. 10.1108/00251740710746033.

Bowen, H. R. (1953). Social responsibility of the businessman. New York: Harper \& Row.

Campbell, L. (2007). Why Would Corporations Behave in Socially Responsible Ways? An Institutional Theory of Corporate Social Responsibility. The Academy of Management Review, 32(3), 946-967. https://doi.org/10.5465/amr.2007.25275684

Carroll, A. (1979). A Three-Dimensional Conceptual Model of Corporate Performance. The Academy of Management Review, 4(4), 497-505. doi: $10.2307 / 257850$

Carroll, A. B. (1991). The pyramid of corporate social responsibility: Toward the moral management of organizational stakeholders. Business horizons, 34(4), 39-48.

Carroll, A. B. (1999). Corporate Social Responsibility: Evolution of a Definitional Construct. Business \& Society, 38(3), 268295. https://doi.org/10.1177/000765039903800303

Carroll, A., \& Shabana, K. (2010). The Business Case for Corporate Social Responsibility: A Review of Concepts, Research and Practice. CGN: Corporate Social Responsibility/Corporate Citizenship

Chin, W.W. (2010). How to Write Up and Report PLS Analyses. In: Esposito Vinzi, V., Chin, W.W., Henseler, J. and Wang, H., Eds., Handbook of Partial Least Squares: Concepts, Methods and Applications, Springer, Heidelberg, Dordrecht, London, New York, 655-690. https://doi.org/10.1007/978-3-540-32827-8_29

Davis, K. (1973). The Case for and against Business Assumption of Social Responsibilities. Academy of Management Journal, 16, 312-323. http://dx.doi.org/10.2307/255331

Chun, R., Da Silva, R., Davies, G., \& Roper, S. (2005). Corporate reputation and competitiveness. Routledge.

Matten, D., \& Moon, J. (2004). Corporate social responsibility. Journal of Business Ethics, 54(4), $323-337$. https://doi.org/10.1007/s10551-004-1822-0

Devinney, T. M. (2009). Is the Socially Responsible Corporation a Myth? The Good, Bad and Ugly of Corporate Social Responsibility. Academy of Management Perspectives, 5, 1-27.

Ferguson, P. D., Deephouse, D. L., \& Ferguson, W. L. (2000). Do strategic groups differ in reputation? Strategic Management Journal, 21(12), $1105-1215$.

Fitzgerald, L., Johnson, R., \& Brignall, S. (1991). Performance Measurement in Service Businesses. CIMA, London.

Fombrun, C.J. (1996). Reputation: Realizing Value from the Corporate Image. Harvard Business School Press, Harvard.

Fombrun, C., Gardberg, N. \& Sever, J. (2000). The Reputation Quotient ${ }^{\mathrm{SM}}$ : A multi-stakeholder measure of corporate reputation. Journal of Brand Management, 7, 241-255. https://doi.org/10.1057/bm.2000.10

Freeman, R.E. (1984). Strategic Management: A Stakeholder Approach, Boston, MA: Pitman Publishing.

Gladwin, T.N. (1993). The global environmental crisis and management education. Environmental Quality Management, 3, 109-114. https://doi.org/10.1002/tqem.3310030111.

Hasan, Z., \& Ali, N. A. (2015). The impact of green marketing strategy on the firm's performance in Malaysia. ProcediaSocial and Behavioral Sciences, 172, 463-470. 10.1016/j.sbspro.2015.01.382.

Hair, J.F., Ringle, C.M., \& Sarstedt, M. (2011). PLS-SEM: Indeed a silver bullet, Journal of Marketing Theory and Practice, 19(2), 139-151.

Hair, J.F., Hult, G.T.M., Ringle, C., \& Sarstedt, M. (2013). A Primer on Partial Least Squares Structural Equation Modeling (PLS-SEM), Sage Publications Ltd, London.

Hair, J.F., Henseler, J., Dijkstra, T., Sarstedt, M., Ringle, C., Diamantopoulos, A., Straub, D., Ketchen, D., GTM, H., \& Calantone, R. (2014). Common beliefs and reality about partial least squares: comments on Rönkkö and Evermann, Organizational Research Methods, 17(2), 182-209.

Hair, J. F., Hult, G. T. M., Ringle, C. M., and Sarstedt, M. (2017). A Primer on Partial Least Squares Structural Equation Modeling (PLS-SEM), 2nd Ed., Sage: Thousand Oaks.

Henseler, J., Ringle, C.M. and Sarstedt, M. (2015). A new criterion for assessing discriminant validity in variance-based structural equation modeling, Journal of the Academy of Marketing Science, 43(1), 115-135.

Henseler, J., Ringle, C.M. and Sinkovics, R.R. (2009). The use of partial least squares path modeling in international marketing, in Sinkovics, R.R. and Ghauri, P.N. (Eds), New Challenges to International Marketing, Emerald Group Publishing Limited.

Johnson, H. T., \& R. S. Kaplan. (1987). Relevance Lost: The Rise and Fall of Management Accounting. Boston: Harvard Business School Press.

Keegan, D. P., Eiler, R. G., \& Jones, C. R. (1989). Are your performance measures obsolete?. Strategic Finance, $70(12), 45$.

Kaplan, R.S., \& Norton, D.P. (1992). The Balanced Scorecard-Measures that Drives Performance. Harvard Business Review, 70(1), 71-79. 
Kärnä, J., Hansen, E., \& Juslin, H. (2003). Environmental activity and forest certification in marketing of forest products - a case study in Europe. Silva Fennica, 37(2), 505-520. https://doi.org/10.14214/sf.505

Lai, C. S., Chiu, C. J., Yang, C. F., \& Pai, D. C. (2010). The effects of corporate social responsibility on brand performance: The mediating effect of industrial brand equity and corporate reputation. Journal of Business Ethics, 95(3), 457-469. https://doi.org/10.1007/s10551-010-0433-1

Le, T., Nguyen, T., Phan, T., Tran, M., Phung, X., Tran, T., \& Giao, K. (2019). Impact of corporate social responsibility on supply chain management and financial performance in Vietnamese garment and textile firms. Uncertain Supply Chain Management, 7(4), 679-690.

Lebas, M., \& Euske, K. (2006). A Conceptual and Operational Delineation of Performance. Business Performance Measurement: Theory and $\quad$ Pratice, $1, \quad 65-79$. https://doi.org/10.1017/CBO9780511753695.006

Li, N. P., Bailey, J. M., Kenrick, D. T., \& Linsenmeier, J. A. (2002). The necessities and luxuries of mate preferences: testing the tradeoffs. Journal of Personality and Social Psychology, 82(6), 947.

Mahon, J. F. (2002). Corporate Reputation: Research Agenda Using Strategy and Stakeholder Literature. Business \& Society, 41(4), 415-445. https://doi.org/10.1177/0007650302238776

Malik, M. (2015). Value-Enhancing Capabilities of CSR: A Brief Review of Contemporary Literature, Journal of Business Ethics, 127(2), 419-438.

Maignan, I., Ferrell, O., \& Ferrell, L. (2005). A stakeholder model for implementing social responsibility in marketing. European Journal of Marketing, 39, 956-977.

Neely, A. (2005). The evolution of performance measurement research: Developments in the last decade and a research agenda for the next. International Journal of Operations \& Production Management, 25(12), 12641277. https://doi.org/10.1108/01443570510633648.

Neville, B. A., \& Menguc, B. (2006). Stakeholder multiplicity: Toward an understanding of the interactions between stakeholders. Journal of Business Ethics, 66(4), 377-391.. https://doi.org/10.1007/s10551-006-0015-4

Nguyen, T., Pham, T., Phan, T., Than, T \& Nguyen, T. (2020). Impact of green supply chain practices on financial and nonfinancial performance of Vietnam's tourism enterprises. Uncertain Supply Chain Management, 8(3), 481-494.

Phan T. T. H., Doan X. T., \& Nguyen T. T. T. (2019). The impact of supply chain practices on performance through supply chain integration in textile and garment industry of Vietnam. Uncertain Supply Chain Management, 8(1), $175-186$.

Phan, T. T. H., Tran, H. X., Le, T. T., Nguyen, N., Pervan, S., \& Tran, M. D. (2020). The Relationship between Sustainable Development Practices and Financial Performance: A Case Study of Textile Firms in Vietnam. Sustainability, 12(15), 5930. https://doi.org/10.3390/su12155930

Phillips, R. (2003). Stakeholder Theory and Organizational Ethics. Berrett-Koehler, San Francisco, CA.

Rindova, V., Williamson, I., Petkova, A., \& Sever, J. (2005). Being Good or Being Known: An Empirical Examination of the Dimensions, Antecedents, and Consequences of Organizational Reputation. The Academy of Management Journal, 48(6), 10331049. doi:10.2307/20159728

Roberts, P. W., \& Dowling, G. R. (2002). Corporate reputation and sustained superior financial performance. Strategic Management Journal, 23(12), 1077-1093. https://doi.org/10.1002/smj.274

Siltaoja, M. E. (2006). Value priorities as combining core factors between CSR and reputation-a qualitative study. Journal of Business Ethics, 68(1), 91-111. https://doi.org/10.1007/s10551-006-

Smaiziene, I., \& Jucevicius, R. (2009). Corporate reputation: Multidisciplinary richness and search for a relevant definition. Engineering Economics/Inžinerine ekonomika, 62(2), 91-101.

Shamma, H. M., \& Hassan, S. S. (2009). Customer and non-customer perspectives for examining corporate reputation. Journal of Product \& Brand Management, 18(5), 326-337. https://doi.org/10.1108/10610420910981800

Taghian, M., D’Souza, C., \& Polonsky, M. (2015). A stakeholder approach to corporate social responsibility, reputation and business performance, Social Responsibility Journal, 11(2), 340-363, doi: 10.1108/SRJ-06-2012-0068.

Tran, M., Phan, T., Ha, H \& Hoang, T. (2020). The impact of transactional leadership on supply chain quality and performance. Uncertain Supply Chain Management, 8(4), 773-784.

Walker, M., Heere, B., Parent, M. M., \& Drane, D. (2010). Social responsibility and the Olympic Games: The mediating role of consumer attributions. Journal of Business Ethics, 95(4), 659-680. https://doi.org/10.1007/s10551-010-0445-x

Wood, D.J., \& Jones, R.E. (1995), Stakeholder mismatching: a theoretical problem in empirical research on corporate social performance. The International Journal of Organizational Analysis, 3(3), 229-267. https://doi.org/10.1108/eb028831

Lii, Y. S., \& Lee, M. (2012). Doing right leads to doing well: When the type of CSR and reputation interact to affect consumer evaluations of the firm. Journal of Business Ethics, 105(1), 69-81. 
Appendix

Table A1

The results of Outer Loadings

\begin{tabular}{|c|c|c|c|c|}
\hline & CR & CSR & FP & SCP \\
\hline CR1 & 0.702 & & & \\
\hline CR2 & 0.843 & & & \\
\hline CR3 & 0.781 & & & \\
\hline CR5 & 0.829 & & & \\
\hline CSR1 & & 0.864 & & \\
\hline CSR10 & & 0.874 & & \\
\hline CSR2 & & 0.760 & & \\
\hline CSR5 & & 0.920 & & \\
\hline CSR6 & & 0.774 & & \\
\hline CSR8 & & 0.863 & & \\
\hline CSR9 & & 0.752 & & \\
\hline FP1 & & & 0.754 & \\
\hline FP2 & & & 0.861 & \\
\hline FP3 & & & 0.817 & \\
\hline FP4 & & & 0.851 & \\
\hline SCP1 & & & & 0.894 \\
\hline SCP3 & & & & 0.784 \\
\hline SCP4 & & & & 0.842 \\
\hline SCP5 & & & & 0.815 \\
\hline
\end{tabular}

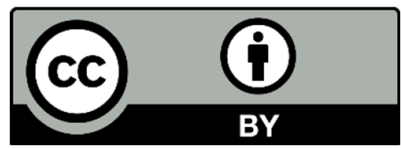

(C) 2021 by the authors; licensee Growing Science, Canada. This is an open access article distributed under the terms and conditions of the Creative Commons Attribution (CCBY) license (http://creativecommons.org/licenses/by/4.0/). 